\title{
Research
}

\section{Salt Marsh Zonal Migration and Ecosystem Service Change in Response to Global Sea Level Rise: A Case Study from an Urban Region}

\author{
$\underline{\text { Rusty A. Feagin }}^{1}, \underline{\text { M. Luisa Martinez }}^{2}$, Gabriela Mendoza-Gonzalez ${ }^{2}$, and $_{\text {Robert Costanza }}^{3}$
}

\begin{abstract}
Coastal wetland plants are expected to respond to global sea level rise by migrating toward higher elevations. Housing, infrastructure, and other anthropogenic modifications are expected to limit the space available for this potential migration. Here, we explore the ecological and economic effects of projected Intergovernmental Panel on Climate Change (IPCC) 2007 report sea level changes at the plant community scale using the highest horizontal $(1 \mathrm{~m})$ and vertical $(0.01 \mathrm{~m})$ resolution data available, using a $6 \times 6 \mathrm{~km}$ area as an example. Our findings show that salt marshes do not always lose land with increasing rates of sea level rise. We found that the lower bound of the IPCC 2007 potential rise $(0.18 \mathrm{~m}$ by 2095) actually increased the total marsh area. This low rise scenario resulted in a net gain in ecosystem service values on public property, whereas market-based economic losses were predicted for private property. The upper rise scenario $(0.59 \mathrm{~m}$ by 2095$)$ resulted in both public and private economic losses for this same area. Our work highlights the trade-offs between public and privately held value under the various IPCC 2007 climate change scenarios. We conclude that as wetlands migrate inland into urbanized regions, their survival is likely to be dependent on the rate of return on property and housing investments.
\end{abstract}

Key Words: coastal ecology; coastal plant migration; sea level rise; spatial analysis

\section{INTRODUCTION}

Coastal salt marsh wetlands are among the world's most productive and valuable ecosystems (Costanza et al. 1989, Costanza et al. 1997, Martínez et al. 2007) and have long adapted to changing sea levels. Nevertheless, there is growing concern as to whether they can withstand the accelerated rise that may come with increased global climate change (Morris et al. 2002, Valiela 2006). Salt marshes are expected to migrate upslope with the rise (Brinson et al. 1995), but human development is expected to limit the potential migration and has already been shown to be a limiting factor to coastal plant species' response patterns (Donnelly and Bertness 2001, Feagin et al. 2005, Desantis et al. 2007).

To better understand the spatially variable effects, models have been used to quantify the potential impacts of climate change-induced sea level rise on coastal systems (Costanza et al. 1990, Titus and Richman 2001) at regional scales (Thieler and Hammar-Klose 2000, McFadden et al. 2007), or with ecosystem scale Sea Level Affecting Marshes
Model (SLAMM)-inspired models (Lee et al. 1992, Craft et al. 2009) and cellular automata (Ross et al. 2009). The simple hypothesis that is typically postulated at the ecosystem scale is that climate change-induced rates of sea level rise will result in the loss of salt marsh wetlands. Moreover, we assume that such a loss is costly because ecosystems provide goods and services upon which human life is sustained (Millenium Ecosystem Assessment 2003, Schröter et al. 2005, Carpenter et al. 2009). However, all previous models have strong limitations in both horizontal (usually $>35 \mathrm{~m}$ ) and vertical resolution (usually $>1.5 \mathrm{~m}$ ) and have thus been unable to discern the differential response of plant community zones and individual species to sea level rise.

Here, our primary objective is to show the divergent ecological effects of the projected United Nations Intergovernmental Panel on Climate Change (IPCC) report (Meehl et al. 2007) sea level changes at the plant community scale using the highest horizontal $(1 \mathrm{~m})$ and vertical $(0.01 \mathrm{~m})$ resolution LIght Detection And Ranging (LIDAR) data 
available. Because the resolution of this model is quite fine, spatially and species-wise, we demonstrate these effects within a discrete $6 \times 6 \mathrm{~km}$ extent. For this same location, our secondary objective is to calculate how the net economic value of the landscape responds to sea level rise.

\section{METHODS}

\section{Study area}

The upper bound on the projected IPCC rise $(0.59$ $\mathrm{m}$; Meehl et al. 2007) in this coming century is quite close to the historically experienced rise $(0.65 \mathrm{~m})$ at our chosen example site of Galveston Island, Texas, USA during the last century. This location provides a uniquely comparable sea level history that is likely to be replicated around the world in the coming century. We do not consider the impact of Hurricane Ike in this analysis because the wetlands were not greatly altered by this storm, either by erosion or accretion (Williams et al. 2009) except along the first meter of wetland-to-open water edge (Feagin et al. 2009), and the property values in the study area have continued to increase on average (Galveston County Appraisal District 2009).

The study area's cross section of Galveston Island, Texas, USA stretches from 29.25 to 29.20 latitude and from -94.87 to -94.94 longitude. The study area is the entirety of the left column images in Figure 1 and is $6192 \times 6192 \mathrm{~m}$ in size. Galveston is a barrier island within the northern Gulf of Mexico, with the Gulf to its south and West Galveston Bay to its north. It has a subtropical climate with cool winters and hot, humid summers. Rain is year-round with maxima in the late spring and early fall.

Coastal salt marshes at the study site exhibited the zonation patterns common to other Spartina alterniflora- dominated marshes in the U.S. Southeast. Plant and animal composition within these distinct zones are strongly related to tidal elevation. Five plant community zones have been previously defined (Feagin and $\mathrm{Wu} 2006$ ) as: open water, including the less than 1 ha of seagrass, Ruppia maritima L., at the site; low marsh, dominated by Spartina alterniflora Loisel with some Salicornia virginica L. and Batis maritima L.; salt flat, i.e., algal crusts plus small stands of Monanthochloe littoralis Engelm., Suaeda linearis (Elliott) Moquin-Tandon, and Salicornia bigelovii Torr.; high marsh, dominated by Spartina patens
(Aiton) Muhl. with some Juncus roemerianus Scheele, and Baccharis halimifolia L.; and upland, mostly Axonopus affinis A. Chase and Paspalum spp., with isolated stands of Tamarix gallica L. and Sapium sebiferum (L.) Roxb., among various other grasses. Because Galveston has been heavily developed, concrete, housing, and non-native plants also compose much of the upland areas. We considered all areas that were not in the open water or various salt marsh zones as upland, whether this upland was developed or natural, concrete or vegetation.

\section{Imagery and classification of plant community zones}

We acquired a $1 \mathrm{~m}$ resolution, 2005 Color Infra-Red (CIR) image of the area and classified areas that were covered by the five zones using the Iterative Self-Organizing Data Analysis Technique (ISODATA) in ENVI image processing software (Research Systems, Inc. 2005, Boulder, Colorado, USA). We then smoothed the image with a $3 \times 3$ majority filter to remove spurious pixels. Ground truthing was performed with a Global Positioning System (GPS) unit (Trimble Pathfinder Pro XRS unit, Trimble Navigation Limited 2005, Sunnyvale, California, USA). GPS points were differentially corrected to an average positional error of $0.3 \mathrm{~m}$.

We also acquired a 2002 LIDAR laser-altimetry dataset of the study area. Mean bias within the dataset was determined with the aid of differentially corrected, GPS points to be $0.01 \mathrm{~m}$ in the horizontal dimension and $0.01 \mathrm{~m}$ in the vertical dimension, with a standard deviation of $0.05 \mathrm{~m}$.

We first defined the elevation ranges at which each of the plant community zones existed by overlaying the LIDAR dataset on top of a classified color infrared image. Utilizing an algorithm that we created in ArcGIS 9.3's Model Builder (Environmental Research Systems Institute 2005, Redlands, California, USA), we sliced the LIDAR data for every $0.01 \mathrm{~m}$ in the vertical dimension, and then found the frequency of occurrence of each classified plant zone across elevation in the NAVD 88 vertical datum. We then assigned discrete elevation ranges that each zone dominated and created an initial state map by placing the zones at their appropriate elevations on the LIDAR dataset, where each pixel was defined as belonging to a particular plant community class based on the defined elevation 
Fig. 1. Plant community zone distribution under various IPCC sea level rise scenarios on Galveston Island, Texas, USA. The study area is considered to be the entirety of the left column images. Red inset boxes relate the coarser-scaled areas (left column images) with the finer-scaled zoomed areas (right column images). Yellow transect lines represent the location of the cross section profiles detailed in Figure 2.

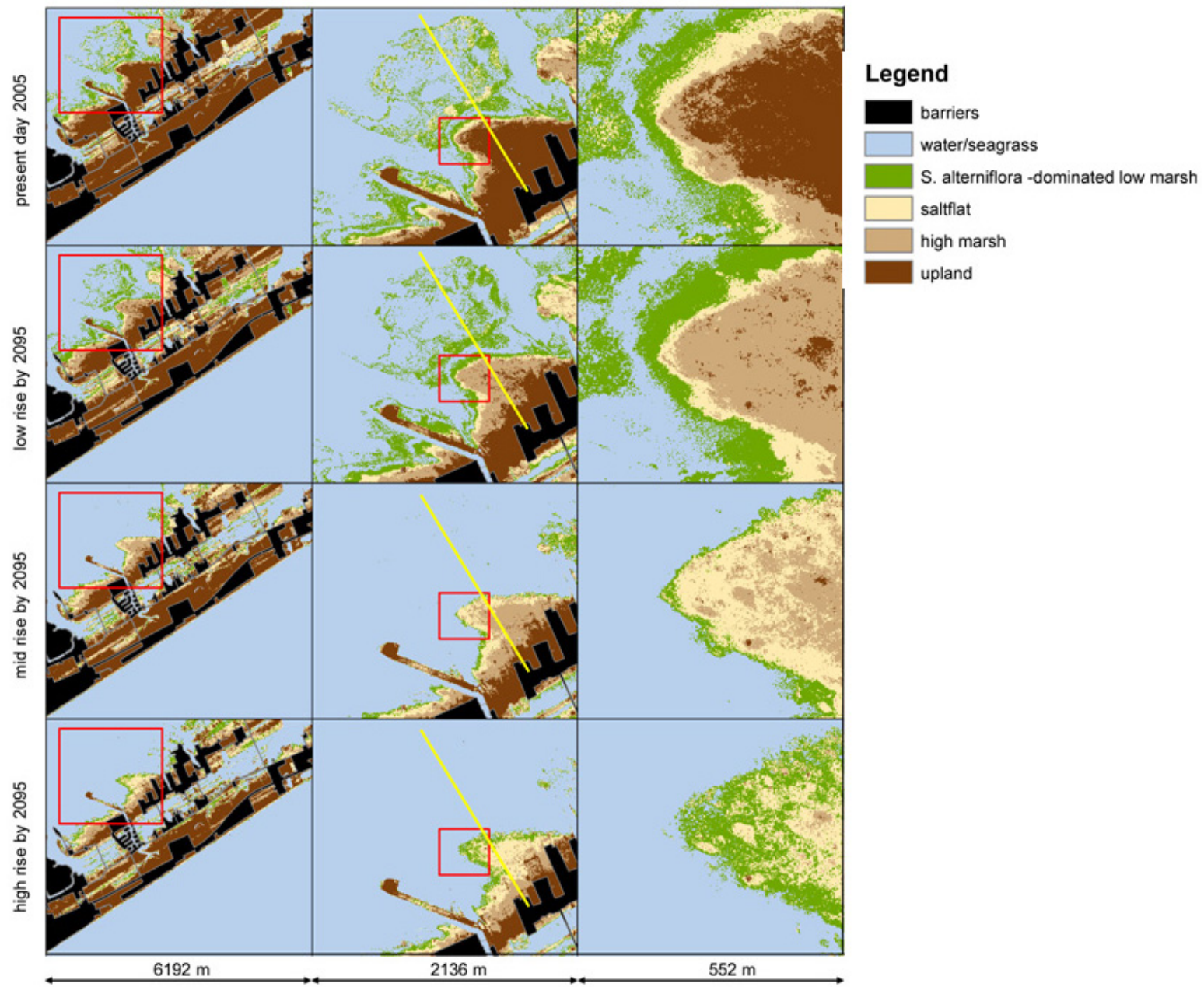

ranges. Thus, we assume that plant zonation is determined entirely by observed response to elevation (McKee and Patrick 1988), but this data is specific to our study site.

The accuracy of the entire procedure was then calculated using the initial state map. We compared the previously collected GPS ground truth data with the map. At the $5 \mathrm{~m}$ resolution, the total accuracy was $90.30 \%$ producer's accuracy (measure of omission errors) and $91.46 \%$ user's accuracy (measure of commission errors). Overall, the accuracy was quite strong considering that the GPS points, from 2005 data, were taken from within $1 \mathrm{~m}$ of a plant zone's edge and that this measure of accuracy incorporated the error from the classification, from 2005 imagery data, as well as the error from the implementation of the range definitions, from 2002 LIDAR DEM data, onto the newly created map; there is a cross-shore, horizontal 
zonal migration rate of around 1-2 $m$ per year in this area due to sea level rise which accounts for the accuracy degradation.

\section{Sea level rise simulations}

A complete scenario began from an initial state map. To implement one time step, the following formula was calculated at each pixel of our plant community scale maps:

$$
e_{t+1}=e_{t}-r(g, s)_{t}+a(e, c)
$$

where $e$ is the elevation, $r$ is the projected relative rise rate as composed of both the global eustatic rate $g$ and the current subsidence rate $s, a$ is the accretion rate as a function of elevation $e$ and plant community class $c$, and $t$ is the time step. There were 20 total time steps from the initial state map to the year 2095 map.

We simulated three IPCC scenarios (Meehl et al. $2007)$ for the eustatic component $g$ : a low rise (0.18 $\mathrm{m}$ by 2095), a mid rise (0.39), and a high maximum rise $(0.59 \mathrm{~m}$ by 2095). From 1909 to the present, the average relative sea level rise rate was $0.65 \mathrm{~cm} / \mathrm{yr}$ at the study site. Approximately 0.32 of this historical rate was due to local subsidence, 0.10 due to regional subsidence, and 0.18 due to eustatic water level rise. Because oil, gas, and water extraction is no longer much of a factor in this area, the current subsidence rate $s$ is only $0.09 \mathrm{~cm} / \mathrm{yr}$ at the study site and much closer to the norm around the world (Feagin et al. 2005).

Pb-210 and Cs-137 cores collected at the site have shown that the accretion rate $a$ has been an average of $0.25 \mathrm{~cm} / \mathrm{yr}$ at the low marsh edge over the historical record, whereas the relative sea level rise rate was considerably higher $(0.65 \mathrm{~cm} / \mathrm{yr})$; there has been a limitation of inorganic sediment in this area (Ravens et al. 2009). The accretion rate was set at $0.25 \mathrm{~cm} / \mathrm{yr}$ for the low marsh at water's edge, regardless of long-shore position. We then modeled the cross-shore variation in the accretion rate using Callaway et al. (1997) as a guide, in which their low marsh, as composed of Spartina alterniflora, accretion rates were found to be roughly double those in what they termed "mid and high" marshes. We therefore set the cross-shore accretion rate in a particular pixel as dependent on its elevation and associated habitat classification: low marsh accretion rates linearly declined from the $0.25 \mathrm{~cm} /$ $\mathrm{yr}$ at the edge as one moved toward higher portions of the low marsh, salt flat and high marsh accretion rates were uniformly $0.125 \mathrm{~cm} / \mathrm{yr}$ and $0.10 \mathrm{~cm} / \mathrm{yr}$, respectively. Given a fixed spatial location over time, as the sea rose, i.e., tidal inundation increased and relative elevation of the pixel became lower, the accretion rate value would accordingly rise. This aspect of the model allowed for wetland accretion rates to be coupled with sea level rise rates, up to the inorganic sedimentary limitation of our study site of $0.25 \mathrm{~cm} / \mathrm{yr}$ (Neubauer 2008, Ravens et al. 2009).

Wave-induced erosion of the marsh edge was simulated by the conversion of all plant community pixels into water pixels that were within a specified distance of the open bay shoreline. This cross-shore erosion rate was on average $0.508 \mathrm{~m} / \mathrm{yr}$ at the study area, yet varied in the long-shore direction at $25 \mathrm{~m}$ intervals, and was based on an empirical, spatially explicit dataset (Gibeaut et al. 2003).

After running the model, we calculated the expected plant habitat loss/gain, both including and excluding potential barriers to plant migration for each of the scenarios in ArcGIS 9.3. Barriers to plant migration were digitized as the extent of all seawalls, bulkheads, parking lots, roads, housing developments, managed lawns, etc. in the 2005 CIR image. When simulations were conducted assuming that these barriers existed, the lands within these outlines remained as uplands, whether this was actually concrete or vegetated uplands, and they could not be encroached upon by the other plant community zonal classes. All calculations were carried out at the $1 \mathrm{~m}^{2}$ scale and converted to hectares for presentation purposes.

\section{Economic valuation}

We calculated ecosystem service values and then estimated losses and gains considering the different sea level rise scenarios. Our goal was to best represent the different plant community zones in this salt marsh relative to one another, in terms of market and nonmarket based values, rather than quantify the absolute value of the total wetland as an average. We first identified the ecosystem services being provided by each plant community at the study site and were able to locate monetary values for five services: recreation, i.e., hunting and bird watching tourism values, carbon sequestration, storm protection, fisheries support, and marketbased property appraisal values (see Appendix). 
Whenever available, we used ecosystem services values previously estimated for the Galveston area or calculated them first hand from publicly available data ourselves (see Appendix). We used three databases when we did not have first hand data: the Environmental Valuation Reference Inventory (EVRI), Envalue, and the Ecosystem Services Database (ESD; McComb et al. 2006). We used the value transfer method in these cases (Wilson and Hoehn 2006) to estimate ecosystem service values, and we specifically point out these cases in the Appendix. When we performed the value transfer method, we were careful to choose only those studies performed either in the Galveston area or in sites similar to it, in terms of economic and social attributes as well as existing ecosystems, to avoid using biased values as much as possible. The ecosystem service values were estimated on a per hectare per year basis. Values were adjusted to US Dollars currency using the Purchasing Power Parity (PPP) and Consumer Price Index (CPI) for 2006, obtained from U.S. government statistics.

We then calculated the total flow of services from each ecosystem by adding the value of each individual service. Our calculated values are higher than general wetland values typically found in the literature (e.g., Woodward and Wui 2001, Brander et al. 2006), but our study area is in the second most productive estuary in the USA in terms of fisheries, directly on the Central Flyway for migratory birds, and embedded within a highly urbanized region; much of our data is specific to location. Moreover, our values are calculated at the plant community zone scale, a much finer resolution than is typical in these generalized studies.

In summary, the low marsh zone had the greatest economic value in terms of ecosystem services in comparison with the other natural ecosystems occurring at the study site (Table 1). This was mainly due to the valuable fisheries supply service and storm protection provided by the low marsh. The salt flat zone had a high recreational value because of the fact that this is prime bird habitat, but had a negative value for carbon sequestration because there is a net $\mathrm{CO}^{2}$ emission by the microbiota in this zone (see Appendix). Similarly, the high marsh recreation value was high, but it also provided a valuable carbon sequestration and storm protection function. The value of the property was moderately high in the uplands, because of a willingness to pay for this land as recorded by the tax appraisal data. This value of the uplands became even higher when the tax appraisal data was allowed to follow the actual rate of $\sim 6 \%$ in this area toward property investment accumulation (Galveston County Appraisal District 2009, Environmental Protection Agency 2000), as opposed to the 3\% rate that the National Oceanic and Atmospheric Administration recommends for marsh valuation and the rate of inflation for general economic services (National Oceanic and Atmospheric Administration 1999). Finally, to estimate gains and losses, we calculated ecosystem service values considering the different areas covered by each ecosystem, given the modeled climate change scenarios.

\section{RESULTS}

\section{Spatial migration of plant community zones}

The zonal migration of the plant community zones primarily depended on the relative sea level rise rate, the accretion rate as specific to zone and location, and the availability of land at a suitable base elevation. However, the choice as to whether human-erected barriers should be removed or kept in place also greatly affected the availability of the land on which this migration could occur.

When compared with the map of plant community zones in 2005 (Fig. 1, top row), the IPCC low rise scenario map appeared somewhat similar for the year 2095 (Fig. 1, second row), except at the high marsh-to-upland interface. The Spartina alterniflora - dominated low marsh zone at the lowest elevations was maintained because the modeled accretion rate $(0.25 \mathrm{~cm} / \mathrm{yr}$ at the seaward edge $)$ was nearly the same as the net relative rise rate $(0.09 \mathrm{~cm} / \mathrm{yr}$ of subsidence plus eustatic rise). At the higher elevations of this zone, elevation was not maintained because accretion rates were less (decreasing to $0.125 \mathrm{~cm} / \mathrm{yr}$ at the upper edge of the low marsh zone) and these locations gradually sank until they assumed the greater accretion rates of the lower elevations of this zone.

Overall, the plant communities increased in extent for the low rise scenario, except for the upland (Table 2). When the model assumed that anthropogenic barriers could limit potential plant migration, upland areas that fell within developed areas were assumed to be protected and less of this land was lost, e.g., in the event of zonal migration, 
Table 1. Economic value of ecosystem services provided by salt marsh zones in the study area. All values are per hectare per year and adjusted to 2006 US Dollars; i.e., \$/ha/yr. Property values contained within ( ) are calculated at $6 \%$ (see text) as opposed to $3 \%$.

\begin{tabular}{|c|c|c|c|c|c|c|}
\hline $\begin{array}{l}\text { Community } \\
\text { zone: }\end{array}$ & $\begin{array}{l}\text { Birding/Hunt } \\
\text { Recreation }\end{array}$ & $\begin{array}{c}\text { Carbon } \\
\text { sequestration }\end{array}$ & $\begin{array}{c}\text { Storm } \\
\text { protection }\end{array}$ & Fisheries & Property & Total \\
\hline water & -- & -- & -- & -- & -- & $4,533.5$ \\
\hline low marsh & $\mathrm{n} / \mathrm{a}$ & $1,204.8$ & $11,748.9$ & $6,943.9$ & $505.4(6,506.4)$ & $\begin{array}{c}20,403.0 \\
(26,403.7)\end{array}$ \\
\hline salt flat & $4,540.2$ & -9.4 & 405.1 & $\mathrm{n} / \mathrm{a}$ & $511.1(6,579.6)$ & $\begin{array}{c}5,447.0 \\
(11,515.5)\end{array}$ \\
\hline high marsh & $4,540.2$ & $1,140.4$ & $1,174.9$ & $\mathrm{n} / \mathrm{a}$ & $\begin{array}{c}865.7 \\
(11,145.4)\end{array}$ & $\begin{array}{c}7,721.0 \\
(18,000.9)\end{array}$ \\
\hline upland & $\mathrm{n} / \mathrm{a}$ & $\mathrm{n} / \mathrm{a}$ & $\mathrm{n} / \mathrm{a}$ & $\mathrm{n} / \mathrm{a}$ & $\begin{array}{c}4,713.8 \\
(60,684.3)\end{array}$ & $\begin{array}{c}4,713.8 \\
(60,684.3)\end{array}$ \\
\hline
\end{tabular}

a housing development, parking lot, or lawn is likely to be raised and/or barricaded so as not to become a marsh plant community. However, the barriers also reduced the amount of land occupied by the other marsh plant communities since they could not migrate into these managed areas.

In the mid rise scenario, there was a net loss of Spartina alterniflora - dominated low marsh, particularly in the large expanse at the back of the island (Fig. 1, third row), but a net gain of salt flats and high marsh as these two plant communities found more locations at suitable elevations as they migrated upslope (Fig. 2). Upland areas showed the greatest net loss, yet this loss was minimized at the expense of the other plant communities when barriers were assumed (Table 2).

Under the IPCC high scenario, the low marsh and salt flat zones surprisingly fared better than in the mid rise scenario because of the topographic relief (Fig. 1, bottom row). The slope appeared to be the primary factor that delimited plant community distribution in the study area (Fig. 2). In this high scenario, the relative rise rate was similar to that which has already occurred in the last century at the study site (0.68 vs. $0.65 \mathrm{~cm} / \mathrm{yr}$, respectively), although the mechanism driving the majority of the relative water rise was different, global eustatic change vs. local subsidence. Historical aerial images at this site detail qualitatively similar losses in the past as those predicted by our high rise scenario maps, given approximately the same relative rise rate, and exhibit similar zonal migration.

\section{Economic consequences}

In the different sea level rise scenarios, it is predicted that, overall, considering all community zones, i.e., water, low marsh, salt flat, high marsh and upland, all the rise possibilities, i.e., IPCC low, mid, and high rise scenarios, with and without barriers to migration, and two different investment accumulation rates on private property $(3 \%, 6 \%)$, the economic losses will generally outweigh the gains (Table 3 ). Our models indicate that there will only be economic gains in Spartina alterniflora-dominated low marshes during a low rise event. In the salt flats and high marsh, net gains result in more available ecosystem services in every scenario, except for the high rise with barriers scenario in the case of the high marsh. The uplands, with large property 
Table 2. Land gained / lost for IPCC sea level rise scenarios at the study area, by plant community zone. Gains are in bold. Units are in hectares.

\begin{tabular}{lccccccc}
\hline \hline & \multicolumn{3}{c}{ No Barriers to Migration } & & \multicolumn{3}{c}{ With Barriers to Migration } \\
\cline { 2 - 4 } \cline { 6 - 8 } Community Zone & Low Rise & Mid Rise & High Rise & & Low Rise & Mid Rise & High Rise \\
\hline water & $\mathbf{+ 2 9}$ & $\mathbf{+ 2 2 8}$ & $\mathbf{+ 3 5 1}$ & & $\mathbf{+ 2 8}$ & $\mathbf{+ 2 2 4}$ & $\mathbf{+ 3 3 9}$ \\
low marsh & $\mathbf{+ 4 2}$ & -32 & -15 & & $\mathbf{+ 4 2}$ & -36 & -24 \\
salt flat & $\mathbf{+ 2 0}$ & $\mathbf{+ 4 2}$ & $\mathbf{+ 5 3}$ & & $\mathbf{+ 1 6}$ & $\mathbf{+ 3 0}$ & $\mathbf{+ 3 2}$ \\
high marsh & $\mathbf{+ 9 5}$ & $\mathbf{+ 7 9}$ & $\mathbf{+ 4 1}$ & & $\mathbf{+ 7 6}$ & $\mathbf{+ 4 4}$ & -8 \\
upland & -186 & -317 & -430 & & -162 & -262 & -339 \\
\hline
\end{tabular}

appraisal values, are likely to show large economic losses in all the projected scenarios, with the largest losses occurring in the high rise scenarios.

If property investments accumulate at a $3 \%$ rate, then the net economic value will be greater when the barriers to plant migration are removed (Table 4). However, if property investments accumulate at a $6 \%$ rate, then leaving the barriers in place will be the optimal solution. This divergence also highlights the trade-offs between public and private value as low marshes and open water are on public property, they are navigable waters and sit below the mean high tide line (Clean Water Act 1972), whereas the other plant communities lay on privately owned land. With strong return on investment into private property and housing, for example the $6 \%$ rate, relative to the return on investment into other market or nonmarket sectors, the opportunity costs of sea level rise increasingly weigh heavily on this investment toward the future, relative to lower rate of return on ecosystem services that exist largely on public land, at the lower 3\% rate, given the same time frame. This finding implies that the appeal of removing barriers to wetland migration may be strongly dependent on market fluctuations in these private property prices. For example, if housing prices declined to zero, or if the investment return rate declined to zero or below, then removing barriers to plant migration would certainly be the optimal economic solution for society.

\section{DISCUSSION}

\section{The natural and social context of salt marsh migration}

Our findings show that a salt marsh does not always lose land with increasing rates of sea level rise. The response of each individual plant community zone is more nuanced, with some zones gaining while others lose land. In a purely natural setting, the future distribution of migrating plants will be largely predetermined by the accretion deficit (Cahoon et al. 1995) at a given location and its interaction with the pre-existing slope.

Direct human activities and intervention in the migration process are estimated to account for the large majority of the losses that are predicted to occur worldwide by the end of this century (Nicholls et al. 1999). Rising sea levels and inflating property values will likely interact as they have in our modeled scenarios, reducing the incentive to save wetlands.

To more generally test the sensitivity of salt marsh loss to changing property values in our study area, we ranged the return rate on private investment from $-0.6 \%$ to $0.6 \%$. As in the primary model, our definition of private investment included housing and property values only. We kept other rates constant at $3 \%$, for example the accumulation rate on the fisheries value. This sensitivity test assumed that the general inflation rate in the economy would 
Fig. 2. Cross section profiles for the various IPCC sea level rise scenarios. Each profile is coordinated with a yellow transect line in Figure 1. Color legend is the same as in Figure 1. The ordinate axis includes all components of relative sea level rise, expressed in NAVD 88 meter units. In these hypsometric representations, 'rising water' is relatively the same as 'sinking land'. The solid black line is present day elevation. The relative elevation ranges at which each plant community zone exists remain the same through time (right side bars), while accretion processes appear to alter the profile shapes slightly in some areas.

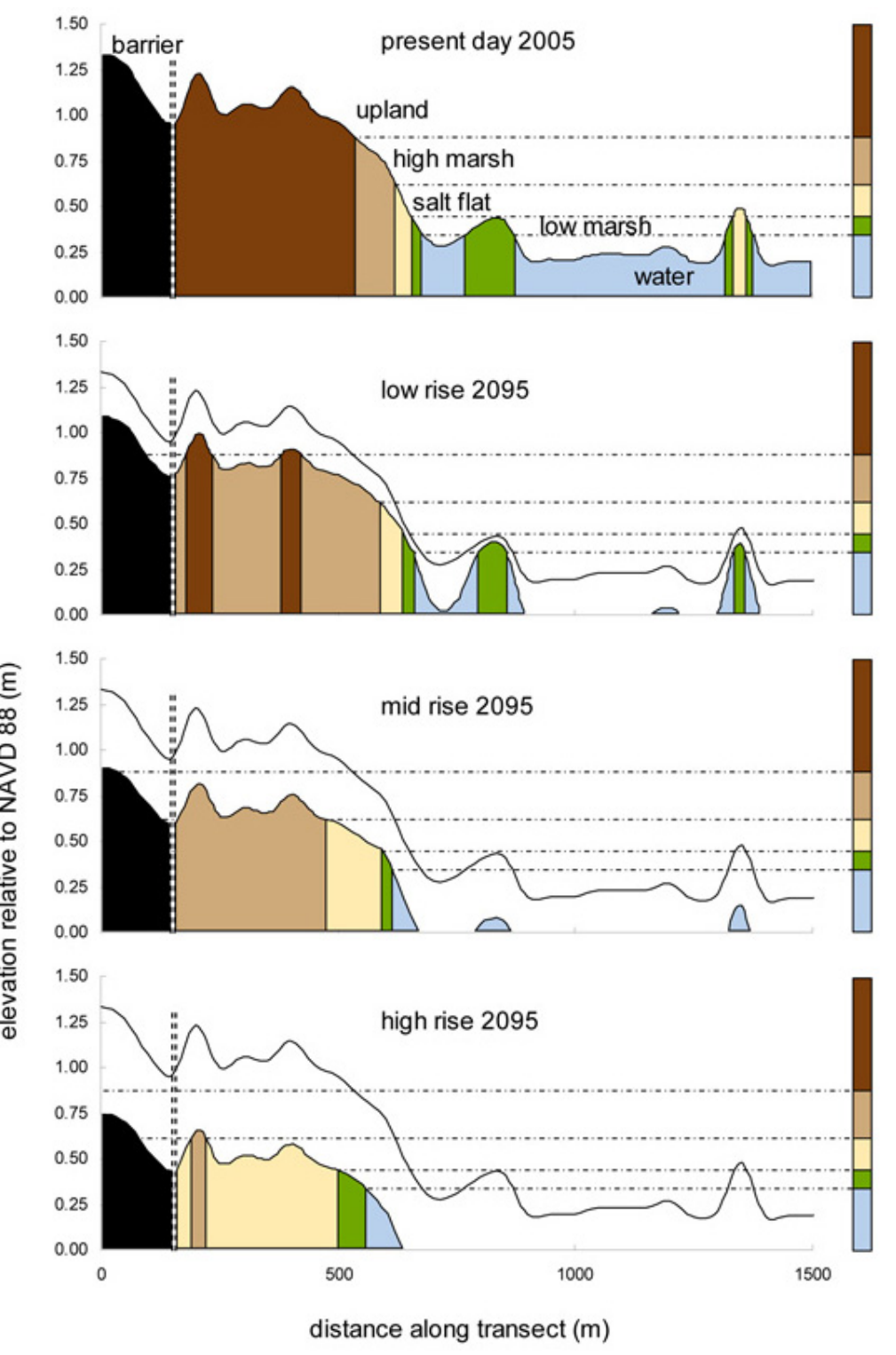


Table 3. Ecosystem services values gained and lost in different IPCC sea level rise scenarios estimated for the study area, Galveston Island, Texas. The upper portion versus lower portions of the table compare two different rates of return on private property investment during the modeled period, $3 \%$ vs. $6 \%$. Gains are in bold. Units are in US Dollars (2006) per year, i.e., \$/yr.

\begin{tabular}{|c|c|c|c|c|c|c|}
\hline \multirow[b]{3}{*}{ Community Zone } & \multicolumn{6}{|c|}{ Private property at $3 \%$ accumulation on investment } \\
\hline & \multicolumn{3}{|c|}{ No Barriers to Migration } & \multicolumn{3}{|c|}{ With Barriers to Migration } \\
\hline & Low Rise & Mid Rise & High Rise & Low Rise & Mid Rise & High Rise \\
\hline water & 131,472 & $1,033,638$ & $1,591,259$ & 126,938 & $1,015,504$ & $1,536,857$ \\
\hline low marsh & 856,926 & $-652,896$ & $-306,045$ & 856,926 & $-734,508$ & $-489,672$ \\
\hline salt flat & 108,940 & 228,774 & 288,691 & 87,152 & 163,410 & 174,304 \\
\hline high marsh & 733,495 & 690,959 & 316,561 & 586,796 & 339,724 & $-61,768$ \\
\hline \multirow[t]{3}{*}{ upland } & $-876,767$ & $-1,494,275$ & $-2,026,934$ & $-763,636$ & $-1,235,016$ & $-1,597,978$ \\
\hline & \multicolumn{6}{|c|}{ Private property at $6 \%$ accumulation on investment } \\
\hline & \multicolumn{3}{|c|}{ No Barriers to Migration } & \multicolumn{3}{|c|}{ With Barriers to Migration } \\
\hline Community zone & Low Rise & Mid Rise & High Rise & Low Rise & Mid Rise & High Rise \\
\hline water & 131,472 & $1,033,638$ & $1,591,259$ & 126,938 & $1,015,504$ & $\mathbf{1 , 5 3 6 , 8 5 7}$ \\
\hline low marsh & $1,108,955$ & $-844,918$ & $-396,056$ & $1,108,955$ & $-950,533$ & $-633,689$ \\
\hline salt flat & 230,310 & 483,651 & 610,322 & 184,248 & 345,465 & 368,496 \\
\hline high marsh & $1,710,086$ & $1, \mathbf{4 2 2 , 0 7 1}$ & 738,037 & $1,368,068$ & 792,040 & $-144,007$ \\
\hline upland & $-11,287,280$ & $-19,236,923$ & $-26,094,249$ & $-9,830,857$ & $-15,899,287$ & $-20,571,978$ \\
\hline
\end{tabular}

be constant at $3 \%$, while property values were also constant at the private investment return rate that was fixed, over the 2005-2095 time period.

We found that net economic losses did not begin in the low rise scenarios until a $4 \%$ private investment rate was exceeded, whereas they began in the high rise scenarios above $2 \%$ (Fig. 3). Thus, if the high rise scenarios come to pass, decisions would likely bias toward keeping the barriers in place and losing the wetlands, even with relatively low rates of return on housing investments. Private property is likely to be saved at the expense of publicly owned jurisdictional lands when this is the most cost efficient outcome (Titus et al. 1991), serves immediate economic needs (Barbier 2006), or has a greater immediate economic return on investment. Similarly, as the private investment rate increased past 3\%, all scenarios began to diverge in magnitude of cost. One can imagine that at high rates of return on private investments, for example $10 \%$, sea level rise would be catastrophic for both private and public interests. Our results show that the financial incentive to secure private property with barriers will increase by several orders of magnitude, given the IPCC high sea level rise scenario over the low rise scenario. 
Table 4. Cost/ benefit of IPCC sea level rise scenarios at the study area, considering ecosystem services provided by publicly owned (low marsh and open water) vs. privately owned properties (salt flat, high marsh, uplands). The upper portion vs. lower portions of the table compare two different rates of return on private property investment during the modeled period, $3 \%$ vs. $6 \%$. Gains are in bold. Units are in US Dollars (2006) per year, i.e., \$/yr.

Private property at $3 \%$ accumulation on investment

\begin{tabular}{lccccccc} 
& \multicolumn{3}{c}{ No Barriers to Migration } & & \multicolumn{3}{c}{ With Barriers to Migration } \\
\cline { 2 - 3 } \cline { 7 - 8 } $\begin{array}{l}\text { Property } \\
\text { ownership }\end{array}$ & Low Rise & Mid Rise & High Rise & & Low Rise & Mid Rise & High Rise \\
\hline public & $\mathbf{9 8 8 , 3 9 8}$ & $\mathbf{3 8 0 , 7 4 2}$ & $\mathbf{1 , 2 8 5 , 2 1 4}$ & & $\mathbf{9 8 3 , 8 6 4}$ & $\mathbf{2 8 0 , 9 9 6}$ & $\mathbf{1 , 0 4 7 , 1 8 5}$ \\
private & $-34,332$ & $-655,542$ & $-1,421,682$ & & $-89,688$ & $-731,882$ & $-1,485,442$ \\
Total & $\mathbf{9 5 4 , 0 6 6}$ & $-274,800$ & $-136,469$ & & $\mathbf{8 9 4 , 1 7 6}$ & $-450,886$ & $-438,258$
\end{tabular}

Private property at $6 \%$ accumulation on investment

\begin{tabular}{|c|c|c|c|c|c|c|}
\hline \multirow[b]{2}{*}{$\begin{array}{l}\text { Property } \\
\text { ownership }\end{array}$} & \multicolumn{3}{|c|}{ No Barriers to Migration } & \multicolumn{3}{|c|}{ With Barriers to Migration } \\
\hline & Low Rise & Mid Rise & High Rise & Low Rise & Mid Rise & High Rise \\
\hline public & $1,240,427$ & 188,720 & $1,195,203$ & $1,235,893$ & 64,971 & 903,168 \\
\hline private & $-9,346,884$ & $-17,331,201$ & $-24,745,891$ & $-8,278,540$ & $-14,761,782$ & $-20,347,489$ \\
\hline Total & $-8,106,457$ & $-17,142,482$ & $-23,550,688$ & $-7,042,647$ & $-14,696,811$ & $-19,444,321$ \\
\hline
\end{tabular}

Human attitudes toward their local environment may turn out to be the primary driver in determining whether coastal ecosystems survive (Nicholls 2004). The protection and conservation of natural ecosystems is necessary and requires the ability to predict the direct and indirect, spatial and temporal effects of human activities, as well as the potential consequences of each decision, e.g., keep or remove barriers for wetland migration, in terms of ecosystem services. The development of coastal infrastructure should take into account the variance among these possible futures (Turner et al. 2007). Moreover, the legal standing of entities impacted by global sea level rise is already being explored, for example in the recent Massachusetts et al. v. Environmental Protection Agency et al. case (Supreme Court of the United States 2006).

\section{Additional factors that may influence salt marsh migration}

A large unknown factor is the relative impact of a hurricane or major storm on our scenarios. Economic losses from property damage, such as those accrued after 2008's Hurricane Ike in our study area, are very likely to surpass immediate economic returns from increasing housing prices. However, and somewhat conversely, housing prices for undamaged properties typically increase after a major storm, as the available housing supply is reduced. For our study area, the majority of properties appear to have increased in value (Galveston County Appraisal District 2009). The potentially increasing impact of hurricanes in climate change scenarios (Emanuel 2005, Webster et al. 2005) needs to be considered when making 
Fig. 3. Effect of the rate of return on private property investment $(\%)$ on the benefit/costs of sea level rise (US Dollars X 107), in the 6 x $6 \mathrm{~km}$ study area on a per year basis.

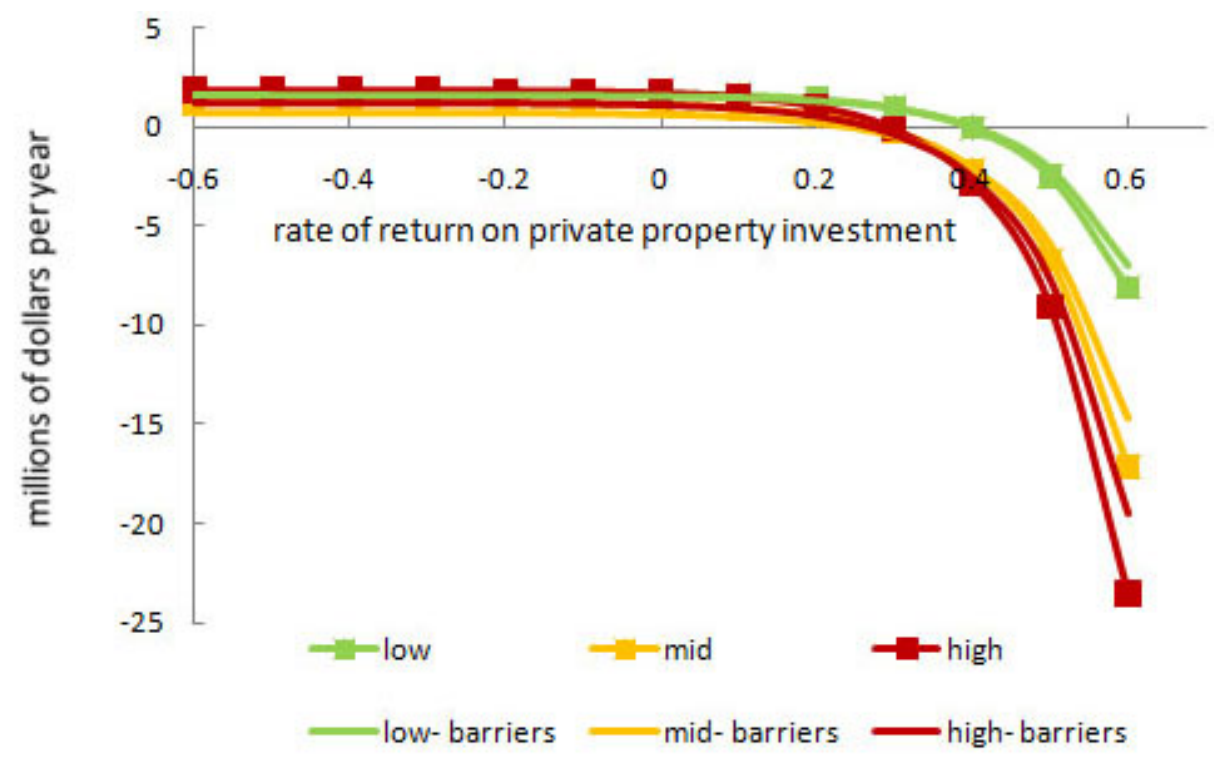

decisions on how to cope with sea level rise. Future work must be done to understand the complex interactions between these two forces (e.g., Ross et al. 2009), as rising base sea levels affect the spatial extent of inundation by storm surges, and to understand their impact on economics and human decision making.

Another unknown factor is the effect that nutrient enrichment may have on our modeled patterns of zonal migration. Levine et al. (1998) introduced a conceptual model suggesting that the competitive hierarchy among marsh plants can be reversed by increasing nutrient availability. In such a scenario, the landward edge of plant zones may then invade and migrate into the seaward edge of the following higher plant zones. At our study site, an N-mediated landward migration is likely to be limited for the Spartina alterniflora -dominated low marsh into the salt flat zone. The abiotic conditions in the salt flat zone are too harsh for any plants to grow, and $\mathrm{N}$ input would not alter the relative ability of plants to survive there. The salt flat to high marsh transition would be similarly unaffected.
However, as Emery et al. (2001) point out, Spartina alterniflora can invade the entirety of the Spartina patens - dominated high marsh zone when enriched with nutrients, regardless of the environmental factors. Minchinton and Bertness (2003) provide an estimated invasion rate of $1.5 \mathrm{~m}$ per year in an example where $\mathrm{N}$ input influences zonal migration, though for Phragmites australis. In our study area, a similar rate for a Spartina alterniflora invasion would allow this species to traverse the entire width of the Spartina patens - dominated high marsh zone by 2095 . We believe that such an invasion could be possible.

Still, the effect of this Spartina alterniflora invasion on the relative benefit/costs of the various sea level rise scenarios would be similar to that which we present in Tables 3 and 4, because the value of 'low marsh' is based on tidal inundation rather than a specific species. For example, though the current high marsh zone could be invaded entirely by Spartina alterniflora, the invaders would remain well above the daily tidal range and thus could not deliver the fishery services of the 'low marsh'. Moreover, the invaders may express themselves 
phenotypically as the short growth form of Spartina alterniflora (Valiela et al. 1978) even with higher $\mathrm{N}$ because of the salinities at our site (Linthurst and Seneca 1981). They may then provide the same provision of services as the high marsh physiognomy at that elevation, i.e., storm protection, avian habitat, etc., though this is ultimately speculation. There are notable exceptions where a species replacement certainly could alter the relative benefit/costs, for example an invasion by Phragmites australis or Tamarix gallica would radically alter the physiognomy (Bertness et al. 2002), though this event is unlikely because of the high salinities present at our study site.

It is likely that $\mathrm{N}$ input would increase production across all plant communities, increasing total biomass and $\mathrm{C}$ sequestration at all fixed spatial locations. Similarly, N enrichment would likely increase aboveground organic accretion rates at all spatial locations (Cahoon and Guntenspergen 2010, Morris et al. 2002), thereby radically altering model output. Moreover, shifts in species distribution across the zones could alter belowground soil and root structures, and further affect the elevation change process.

More work is needed to assess the effect of increased $\mathrm{N}$ on the other ecosystem services that we list in Table 1 . However, we predict that increasing $\mathrm{N}$ may reduce the fisheries value of the low marsh, because it may reduce the tortuosity of the open water-tolow marsh edge within the marsh (Feagin and $\mathrm{Wu}$ 2006), and increase the storm protection value, though an increase in standing biomass is not likely to be linearly related to increased storm protection. Future modeling work could focus on the withinzone, and species-specific, dynamics of adding $\mathrm{N}$ to the marsh ecosystem.

Another unknown factor is whether potentially increasing $\mathrm{CO}_{2}$ concentrations or temperatures will have an influence on marsh accretion, although some initial work has shown that this process may present a counter-weight to the rising sea (Kirwan et al. 2009, Langley et al. 2009). However, another unknown is whether specific 'tipping elements', such as the West Antarctic Ice Sheet or the Greenland Ice Sheet, will contribute more water to the rise than the IPCC report suggests (Tol et al. 2006, Lenton et al. 2008). More will need to be known about the magnitude of climate change, biotic interactions among species in a salt marsh, species-specific ecosystem service values, and the complexities of the socioeconomic marketplace to make our predictions even better in the future.

\section{CONCLUSION}

Our work highlights the trade-offs between public and privately held value under the various IPCC climate change scenarios in urbanized regions. We conclude that as wetlands migrate landward, their survival is also dependent on the rate of return on property and housing investments. Investigations at our example site had to be scaled to the plant community zone/species level to resolve the actual impact to the whole ecosystem, and to take into account the benefit/costs among sea level rise scenarios, local sources of geomorphic variability, and trade-offs between public vs. private lands. We similarly expect that local conditions and human proclivities will radically differentiate the benefit/ costs of sea level rise at other locations around the world.

Responses to this article can be read online at: http://www.ecologyandsociety.org/vol15/iss4/art14/ responses/

\section{Acknowledgments:}

We would like to thank Fitzwilliam College and the University of Cambridge for providing support during a portion of this project.

\section{LITERATURE CITED}

Barbier, E. B. 2006. Natural barriers to natural disasters: replanting mangroves after the tsunami. Frontiers in Ecology and the Environment 4:124-131.

Bertness, M. D., P. Ewanchuk, and B. R. Silliman 2002. Anthropogenic modification of New England salt marsh landscapes. Proceedings of the National Academy of Sciences USA 99:1395-1398.

Brander, L. M., R. J. G. M. Florax, and J. E. Vermaat. 2006. The empirics of wetland valuation: a comprehensive summary and a meta-analysis of the literature. Environmental Resource Economics 33:223-250 
Brinson, M. M., R. R. Christian, and L. K. Blum. 1995. Multiple states in the sea-level induced transition from terrestrial forest to estuary. Estuaries 18:648-659.

Cahoon, D. R., and G. R. Guntenspergen. 2010. Climate change, sea-level rise, and coastal wetlands. National Wetlands Newsletter 32:8-12.

Cahoon, D. R., D. J. Reed, and J. W. Day, Jr. 1995. Estimating shallow subsidence in microtidal salt marshes of the southeastern United States: Kaye and Barghoorn revisited. Marine Geology 128:1-9.

Callaway, J. C., R. D. DeLaune, and W. H. Patrick, Jr. 1997 Sediment accretion rates from four coastal wetlands along the Gulf of Mexico. Journal of Coastal Research 13:181-191.

Carpenter, S. R., H. A. Mooney, J. Agard, D. Capistrano, R. S. DeFries, S. Diaz, T. Dietz, A. K. Duraiappah, A. Oteng-Yeboah, H. M. Pereira, C. Perrings, W. V. Reid, J. Sarukhan, R. J. Scholes, and A. Whyte. 2009. Science for managing ecosystem services: beyond the Millenium Ecosystem Assessment. Proceedings of the National Academy of Sciences USA 106:1305-1312.

Clean Water Act. 1972. Clean Water Act Section 404. U.S. Code Title 33, § 1344. [online] URL: htt p://frwebgate.access.gpo.gov/cgi-bin/getdoc.cgi?dbname= browse usc \&docid=Cite:+33USC1344".

Costanza R., R. d'Arge, R. de Groot, S. Farber, M. Grasso, B. Hannon, K. Limburg, S. Naeem, R. V. O'Neill, J. Paruelo, R. G. Raskin, P. Sutton, and M. van den Belt. 1997. The value of the world's ecosystem services and natural capital. Nature 387:253-260.

Costanza, R., S. C. Farber, and J. Maxwell. 1989. The valuation and management of wetland ecosystems. Ecological Economics 1:335-361.

Costanza R., F. H. Sklar, and M. L. White. 1990. Modeling coastal landscape dynamics. BioScience 40:91-107.

Craft C. B., J. Clough, J. Ehman, S. B. Joye, R. Park, S. C. Pennings, H. Guo, and $M$. Machmuller. 2009. Forecasting the effects of accelerated sea level rise on tidal marsh ecosystem services. Frontiers in Ecology and the Environment 7:73-78.
Desantis, L. R. G., S. Bhotika, K. Williams, and F. E. Putz. 2007. Sea-level rise and drought interactions accelerate forest decline on the Gulf Coast of Florida, USA. Global Change Biology 13:2349-2360.

Donnelly, J. P., and M. D. Bertness. 2001. Rapid shoreward encroachment of salt marsh cordgrass in response to accelerated sea-level rise. Proceedings of the National Academy of Sciences USA 98:14218-14223.

Emanuel, K. 2005. Increasing destructiveness of tropical cyclones over the past 30 years. Nature 436:686-688.

Emery, N. C., P. J. Ewanchuk, and M. D. Bertness. 2001. Competition and salt-marsh plant zonation: stress tolerators may be dominant competitors. Ecology 82:2471-2485.

Environmental Protection Agency (EPA). 2000. Guidelines for preparing economic analyses. United States Environmental Protection Agency, Office of the Adminstrator, EPA 240-R-00-003, Washington, D.C., USA. [online] URL: http://yosemite.epa.gov/ ee/epa/eed.nsf/webpages/Guidelines.html/\$file/Guidelines. pdf.

Feagin, R. A., S. M. Lozada-Bernard, T. Ravens, I. Möller, K. M. Yeager, and A. H. Baird. 2009. Does vegetation prevent wave erosion of salt marsh edges? Proceedings of the National Academy of Sciences USA 106:10109-10113.

Feagin, R. A., D. J. Sherman, and W. E. Grant. 2005. Coastal erosion, global sea-level rise, and the loss of sand dune plant habitats. Frontiers in Ecology and the Environment 3:359-364.

Feagin, R. A., and X. B. Wu. 2006. Spatial pattern and edge characteristics in restored terrace versus reference salt marshes in Galveston Bay. Wetlands 26:1004-1011.

Galveston County Appraisal District. 2009. Available online at: http://www.galvestoncad.org/PA/ Shapeidx/shapes.htm.

Gibeaut, J. C., R. Waldinger, T. Hepner, T. A. Tremblay, and W.A. White. 2003. Changes in Bay Shoreline Position, West Bay System, Texas. Report to the Texas General Land Office 02-225R, Bureau of Economic Geology, University of Texas at 
Austin, Austin, Texas, USA. [online] URL: http:// www.beg.utexas.edu/coastal/presentations reports/ WestBayfinalreport.pdf.

Kirwan, M. L., G. R. Guntenspergen, and J. T. Morris. 2009. Latitudinal trends in Spartina alterniflora productivity and the response of coastal marshes to global change. Global Change Biology 15:1982-1989.

Langley, J. A., K. L. McKee, D. R. Cahoon, J. A. Cherry, and J. P. Megonigal. 2009. Elevated $\mathrm{CO}_{2}$ stimulates marsh elevation gain, counterbalancing sea-level rise. Proceedings of the National Academy of Sciences USA 106:6182-6186.

Lee, J. K., R. A. Park, and P. W. Mausel. 1992. Application of geoprocessing and simulation modeling to estimate impacts of sea level rise on the Northeast Coast of Florida. Photogrammetric Engineering and Remote Sensing 58:1579-1586.

Lenton, T. A., H. Held, E. Kriegler, J. W. Hall, W. Lucht, S. Ramstorf, and H. J. Schellnhuber. 2008. Tipping elements in the earth's climate system. Proceedings of the National Academy of Sciences USA 105:1786-1793.

Levine, J. M., J. S. Brewer, and M. D. Bertness. 1998. Nutrients, competition, and plant zonation. Journal of Ecology 86:285-292.

Linthurst, R.A., and E.D.Seneca. 1981. Aeration, nitrogen, and salinity as determinants of Spartina alterniflora Loisel. Growth response. Estuaries 4:53-63.

Martínez, M. L., A. Intralawan, G. Vázquez, O. M. Pérez-Maqueo, P. Sutton, and R. Landgrave. 2007. The coasts of our world: ecological, economic and social importance. Ecological Economics 63:254-272.

McComb, G., V. Lantz, K. Nash, and R. Rittmaster. 2006. International valuation databases: overview, methods and operational issues. Ecological Economics 60:461-472.

McFadden, L., T. Spencer, and R. J. Nicholls. 2007. Broad-scale modeling of coastal wetlands: what is required? Hydrobiologia 577:5-15.

McKee, K. L., and W. H. Patrick, Jr. 1988. The relationship of smooth cordgrass (Spartina alterniflora) to tidal datums: a review. Estuaries 11:143-151.

Meehl, G. A., T. F. Stocker, W. D. Collins, P. Friedlingstein, A. T. Gaye, J. M. Gregory, A. Kitoh, R. Knutti, J. M. Murphy, A. Noda, S. C. B. Raper, I. G. Watterson, A. J. Weaver and Z.C.Zhao. 2007. Global Climate Projections. Chapter 10 in S. Solomon, D. Qin, M. Manning, Z. Chen, M. Marquis, K. B. Averyt, M. Tignor and H. L. Miller, editors. Climate Change 2007: The Physical Science Basis. Contribution of Working Group I to the Fourth Assessment Report of the Intergovernmental Panel on Climate Change. Cambridge University Press, Cambridge, UK and New York, New York, USA.

Millenium Ecosystem Assessment. 2003. Ecosystems and human well-being: a frameworkfor assessment. Island Press, Washington, D.C., USA.

Minchinton, T. E., and M. D. Bertness. 2003. Disturbance-mediated competition and the spread of Phragmites australis in a coastal marsh. Ecological Applications 13:1400-1416.

Morris, J. T., P. V. Sundareshwar, C. T. Nietch, B. Kjerfve, and D. R. Cahoon. 2002. Responses of coastal wetlands to rising sea level. Ecology 83:2869-2877.

National Oceanic and Atmospheric Administration. 1999. Discounting and the treatment of uncertainty in natural resource damage assessment. Technical Paper 99-. Damage Assessment and Restoration Program, National Oceanic and Atmospheric Administration (NOAA), Silver Spring, Maryland, USA. [online] URL: http://www.darrp.noaa.gov/ec onomics/pdf/discpdf2.pdf.

Neubauer, S. C. 2008. Contributions of mineral and organic components to tidal freshwater marsh accretion. Estuarine, Coastal and Shelf Science 78:78-88.

Nicholls, R. J. 2004. Coastal flooding and wetland loss in the 21st century: changes under the SRES climate and socio-economic scenarios. Global Environmental Change 14:69-86.

Nicholls, R. J., F. M. J. Hoozemans, and M. Marchand. 1999. Increasing flood risk and wetland losses due to global sea-level rise: regional and 
global analyses. Global Environmental Change 9: S69-S87.

Ravens, T. M., R. C. Thomas, K. A. Roberts, and P. H. Santschi. 2009. Causes of salt marsh erosion in Galveston Bay, Texas. Journal of Coastal Research 25:265-272.

Ross, M. S., J. J. O'Brien, R. G. Ford, K. Zhang, and A. Morkill. 2009. Disturbance and the rising tide: the challenge of biodiversity management for low island ecosystems. Frontiers in Ecology and Environment 7:471-478.

Schröter, D., W. Cramer, R. Leemans , C. I. Prentice, M. B.Araújo, N. W.Arnell,A. Bondeau, H. Bugmann, T. R. Carter, C. A. Gracia, A. C. de la Vega-Leinert, M. Erhard, F. Ewert, M. Glendining, J. I. House, S. Kankaanpää, R. J. T. Klein, S. Lavorel, M. Lindner, M. J. Metzger, J. Meyer, T. D. Mitchell, I. Reginster, M. Rounsevell, S. Sabaté, S. Sitch, B. Smith, J. Smith, P. Smith, M. T. Sykes, K. Thonicke, W. Thuiller, G. Tuck, S. Zaehle, and B. Zierl. 2005. Ecosystem service supply and vulnerability to global change in Europe. Science 310:1333-1337.

Supreme Court of the United States. 2006. Massachusetts et al. v. Environmental Protection Agency et al. Slip Opinion No. 05-1120. [online] URL: http://www.supremecourt.gov/opinions/06pd f/05-1120.pdf.

Thieler, E. R., and E. S. Hammar-Klose. 2000. National assessment of coastal vulnerability to future sea-level rise: preliminary results for the US Gulf of Mexico coast. USGS Open-File Report 00179. [online] URL: http://pubs.usgs.gov/dds/dds68/

Titus, J. G., R. A. Park, S. P. Leatherman, J. R. Weggel, M. S. Greene, P. W. Mausel, S. Brown, G. Gaunt, M. Trehan, and G. Yohe. 1991. Greenhouse effect and sea level rise: the cost of holding back the sea. Coastal Management 19:171-204.

Titus, J. G., and C. Richman. 2001. Maps of lands vulnerable to sea level rise: modeled elevations along the US Atlantic and Gulf coasts. Climate Research 18:205-228.

Tol, R. S. J., M. Bohn, T. E. Downing, M.-L. Guillerminet, E. Hizsnyik, R. Kasperson, K.
Lonsdale, C. Mays, R. J. Nicholls, A. A. Olsthoorn, G. Pfeifle, M. Poumadere, F. L. Toth, A. T. Vafeidis, P. E. van der Werff, and I. H. Yetkiner. 2006. Adaptation to five meters of sea level rise. Journal of Risk Research 9:467-482.

Turner, R. K., D. Burgess, D. Hadley, E. Coombes, and N. Jackson. 2007. A cost-benefit appraisal of coastal managed realignment policy. Global Environmental Change 17:397-407.

Valiela, I. 2006. Global Coastal Change. Blackwell Publishing, Oxford, UK.

Valiela, I., J. M. Teal, and W. G. Deuser. 1978. The nature of growth forms in the salt marsh grass Spartina alterniflora. American Naturalist 112:461-470.

Webster, P., J. Holland, G. J. Curry, and H. R. Chang. 2005. Changes in tropical cyclone number, duration, and intensity in a warming environment. Science 309: 1844-1846.

Williams, A. M., R. A. Feagin, W. K. Smith, and N. L. Jackson. 2009. Ecosystem impacts of Hurricane Ike on Bolivar Peninsula and Galveston Island: perspectives of the Coastal Barrier Island Network (CBIN). Shore \& Beach 77:71-76.

Wilson, M. A., and J. P. Hoehn. 2006. Valuing environmental goods and services using benefit transfer: the state-of-the art and science. Ecological Economics 60:335-342.

Woodward, R. T., and Y.-S. Wui. 2001. The economic value of wetland services: a metaanalysis. Ecological Economics 37:257-270. 


\section{APPENDIX}

\section{Ecosystem Service Valuation}

Recreation (hunting and bird watching tourism) is dependent upon the resources in the salt flat and high marsh zones, as this is where the birds forage and reside. We calculated this value similarly in both zones. The bird watching tourism value was taken as the average willingness to pay and consumer surplus per recreation benefits, \$3,243.0 ha/yr, a value transferred from three coastal sites in South Texas from Mathis and Matishoff (2004), and thus may represent a small source of error. However, because studies specific to the Galveston Bay area show similar per day per person expenditures (Bell 1997), although without the per hectare estimates that we needed for this analysis, the transfer should be appropriate. Texas hunters spend 2.5 times less than birdwatchers on average (Adams et al. 1997) for a value of $\$ 1,297.2$ $\mathrm{ha} / \mathrm{yr}$. We thus calculate the total for hunting and bird watching tourism as $\$ 4,540.2 \mathrm{ha} / \mathrm{yr}$.

The carbon sequestration value was calculated as the average yearly net carbon sequestration or production in a plant community zone, multiplied by the near-future average market cost to sequester carbon, \$20 (Department of Energy 2009). Average yearly net carbon was calculated as 60,240 kg C/ha/yr for Spartina alterniflora - dominated low marsh and 57,020 $\mathrm{kg} \mathrm{C/ha/yr} \mathrm{for} \mathrm{Spartina} \mathrm{patens} \mathrm{-} \mathrm{dominated} \mathrm{high} \mathrm{marsh,} \mathrm{with} \mathrm{the} \mathrm{assumption} \mathrm{that} \mathrm{this} \mathrm{yield} \mathrm{is}$ directly transferable from Pezeshki and Delaune (1991) in Louisiana to our site in Texas as the climate, species, and plant community zones are nearly identical. For the seasonally-inundated algal salt flat, we assumed that the average yearly net carbon was $-470 \mathrm{~kg} \mathrm{C} / \mathrm{ha} / \mathrm{yr}$, which represents a gross value for an algal mat that subtracts the bacterial respiration (Cammen 1991). This value was transferred from data taken during a summer in New England and thus may represent a potential source of error.

The storm protection value was directly calculated as the avoidance cost value for the vegetated marsh with respect to storms in the Galveston, TX region from historical data; see Costanza et al. (2008) for methodological details. This value was calculated separately for the low marsh and high marsh. Salt flat values were assumed to be $1 / 2.9$ of those of the vegetated high marsh, as this is the difference in wave reduction between vegetated and unvegetated areas at the same elevation (Möller et al. 1999). Our assumption for this calculation is that the salt flat zone and the high marsh zone occupy the same general elevation.

For fisheries value, we calculated the average replacement cost value for fishery restoration projects in the Galveston, TX area at \$45,012.4 per hectare as based upon Table 7 in Rozas et al. (2005). Since this data source did not present per year estimates, we then calculated the future value at the end of the model runs (year 2095) at a compounded 3\% annual rate of accumulation from their current value (2006); this represents the rate at which monetary gains are accumulated (ie, reverse of 'discounting'; National Oceanic and Atmospheric Administration 1999). This is the rate recommended by National Oceanic and Atmospheric Administration for fishery-based restoration values, eg our data source. The resulting annualized value is independent from inflation and remains in 2006 US Dollars. 
For property values, we first found the market value for each parcel and attending housing improvement within the study area, using tax appraisal data from Galveston County Appraisal District (2009). We then estimated the value of every square meter (1 x $1 \mathrm{~m}$ pixel) within a parcel, as based upon the total value of a parcel and improvement divided by its area. Next, we found the plant community zone that occupied each pixel, and summarized the values from every pixel in the study area according to plant community zone. This allowed us to find the average value for a square meter of the four plant community zones, within our study area. We then converted this average value into hectares. Similar to the fisheries value, we calculated private property accumulation rates following the methodology described above at the 3\% rate, as well calculating at the current market 6\% rate (Galveston County Appraisal District 2009, Environmental Protection Agency 2000), in order to estimate the effect of property investment relative to ecosystem services. Currently, property values are still increasing in this area as opposed to much of the USA, even after 2008's Hurricane Ike (as caused by lower supply of housing, as well as relatively good economic climate in this area).

We then calculated the total flow of services from each ecosystem by adding the value of each individual service (except for open water, which we calculated as a total as the available literature allowed, yet specifically for the Galveston Bay area, eg Whittington et al. 1994).

\section{Appendix Literature Cited}

Adams, C. E., J. A. Leifester, and J. S. C. Herron. 1997. Understanding wildlife constituents: birders and waterfowl hunters. Wildlife Society Bulletin 25: 653-660.

Bell, F.W. 1997. The economic valuation of saltwater marsh supporting marine recreational fishing in the Southeastern United States. Ecological Economics 21: 243-254.

Cammen, L.M. 1991. Annual bacterial production in relation to benthic microalgal production and sediment oxygen uptake in an intertidal sandflat and an intertidal mudflat. Marine Ecology Progress Series 71:13-25.

Costanza, R, O. M. Pérez-Maqueo, M. L. Martínez, P. Sutton, S. J. Anderson, and K. Mulder. 2008. The value of coastal wetlands for hurricane protection. Ambio 37:241-248.

Department of Energy. 2009. Available online at: http://www.fossil.energy.gov/sequestration/overview.html.

Environmental Protection Agency. 2000. Guidelines for preparing economic analyses. United States Environmental Protection Agency (EPA), Washington DC. EPA 240-R-00-003. Available online at: http://yosemite.epa.gov/ee/epa/eed.nsf/webpages/Guidelines.html/\$file/Guidelines.pdf.

Galveston County Appraisal District. 2009. Available online at: http://www.galvestoncad.org/PA/Shapeidx/shapes.htm. 
Mathis, M., and D. Matisoff. 2004. A characterization of ecotourism in the Texas Lower Rio Grande Valley. Report of the Houston Advanced Research Center VNT-04-01, Houston, Texas, USA.

Möller, I., T. Spencer, J. R. French, D. J. Leggett, and M. Dixon. 1999. Wave transformation over salt marshes: a field and numerical modeling study from North Norfolk, England. Estuarine, Coastal and Shelf Science 49:411-426.

Pezeshki, S. R., and R. D. DeLaune.1991. Ecophenic variation in Spartina patens: growth and biomass partitioning. Journal of Aquatic Plant Management 29: 99-102.

Rozas, L. P., P. Caldwell, and T. J. Minello. 2005. The fishery value of salt marsh restoration projects. Journal of Coastal Research Special Issue 40:37-50.

National Oceanic and Atmospheric Administration. 1999. Discounting and the treatment of uncertainty in natural resource damage assessment. Technical Paper 99-1, Damage Assessment and Restoration Program, National Oceanic and Atmospheric Administration (NOAA), Silver Spring, Maryland, USA. Available online at: http://www.csc.noaa.gov/coastal/economics/discounting.htm.

Whittington, D., G. Cassidy, D. Amaral, E. McClelland, H. Wang, and C. Poulos. 1994. The economic value of improving the environmental quality of Galveston Bay. Report to Galveston Bay Estuary Program GBEP-38 6/94, Department of Environmental Sciences and Engineering, University of North Carolina at Chapel Hill, North Carolina, USA. 